\title{
Thermal adaptability of Kluyveromyces marxianus in recombinant protein production
}

\author{
Stefano Raimondi ${ }^{1}$, Elena Zanni ${ }^{2}$, Alberto Amaretti ${ }^{1}$, Claudio Palleschi ${ }^{2}$, Daniela Uccelletti ${ }^{*}$ and Maddalena Rossi ${ }^{*}$
}

\begin{abstract}
Background: Kluyveromyces marxianus combines the ease of genetic manipulation and fermentation with the ability to efficiently secrete high molecular weight proteins, performing eukaryotic post-translational modifications. It is able to grow efficiently in a wide range of temperatures. The secretion performances were analyzed in the host K. marxianus $\mathrm{L} 3$ in the range between $5^{\circ} \mathrm{C}$ and $40^{\circ} \mathrm{C}$ by means of 3 different reporter proteins, since temperature appears a key parameter for production and secretion of recombinant proteins.

Results: The recombinant strains were able to grow up to $40^{\circ} \mathrm{C}$ and, along the tested temperature interval $\left(5-40^{\circ} \mathrm{C}\right)$, the specific growth rates $(\mu)$ were generally lower as compared to those of the untransformed strain. Biomass yields were slightly affected by temperature, with the highest values reached at $15^{\circ} \mathrm{C}$ and $30^{\circ} \mathrm{C}$. The secretion of the endogenous $\beta$-fructofuranosidase, used as an internal control, was efficient in the range of the tested temperature, as evaluated by assaying the enzyme activity in the culture supernatants. The endogenous $\beta$-fructofuranosidase production was temperature dependent, with the highest yield at $30^{\circ} \mathrm{C}$. The heterologous proteins HSA, GAA and Sod $1 \mathrm{p}$ were all successfully produced and secreted between $5^{\circ} \mathrm{C}$ and $40^{\circ} \mathrm{C}$, albeit each one presented a different optimal production temperature $\left(15,40,5-30^{\circ} \mathrm{C}\right.$ for HSA, GAA and Sod $1 \mathrm{p}$, respectively).

Conclusions: K. marxianus L3 has been identified as a promising and flexible cell factory. In a sole host, the optimization of growth temperatures for the efficient secretion of each individual protein can be carried out over a wide range of temperatures.
\end{abstract}

\section{Background}

Kluyveromyces marxianus is one of the alternative yeasts for which an efficient transformation system was developed [1]. It has a long history of usage in food fermentation, and holds the GRAS status (Generally Regarded As Safe) that allows straightforward food and pharmaceutical applications of this microorganism and its derivatives [2]. $K$. marxianus grows on cheap lactose based media, such as whey and inulin, ferments xylose to ethanol, and does not require expensive explosion-proof plants which are necessary for methylotrophic yeasts [3,4].

Ethanol production represents one of the pivotal field of K. marxianus utilization. In the fermentation of renewable biomass residues, its capability to simultaneously consume glucose and xylose can be exploited in order to maximize

\footnotetext{
* Correspondence: daniela.uccelletti@uniroma1.it; maddalena.rossi@unimore.it 'Department of Life Sciences, University of Modena and Reggio Emilia, Via Campi 183, 41125, Modena, Italy

${ }^{2}$ Department of Biology and Biotechnology Charles Darwin, University of Rome "La Sapienza", Piazzale Aldo Moro 5, 00185, Rome, Italy
}

ethanol productivity [4]. Recently, K. marxianus was also employed for tequila production at industrial level: the strain showed a higher osmotic $(22 \% \mathrm{w} / \mathrm{v})$ and ethanol $(10 \% \mathrm{v} / \mathrm{v})$ tolerance, producing high levels of volatiles [5].

However, the intrinsic advantages of $K$. marxianus over other yeasts will be better utilized for a variety of biotechnological applications as more and well-defined genetic engineering tools will become available. Recently, four $S$. cerevisiae promoters were characterized in $K$. marxianus for promoter strength, time-dependent changes, and stochastic gene expression pattern [6]. In addition, the genome of the thermotolerant $K$. marxianus KCTC 17555 that can convert inulin-rich plant biomass into ethanol and/or platform biochemicals was sequenced and analysed [7].

For heterologous gene expression, $K$. marxianus represents a valid alternative because of its outstanding secretory capabilities [8-10]. K. marxianus can also produce eukaryotic proteins since it modifies foreign proteins according to a general eukaryotic scheme. Moreover, $K$. marxianus has been exploited as a cell factory to obtain 
valuable enzymes, showing retention of activity in a large temperature interval [11].

A peculiar trait of this yeast is the capacity to grow within a wide interval of temperatures, ranging from $4^{\circ} \mathrm{C}$ to $45^{\circ} \mathrm{C}$. This feature has been investigated in a study where the adaptive responses at different temperatures of psychrophilic and mesophilic yeasts were compared [12]. The main objective of the current study was to explore the capability of $K$. marxianus to secrete various heterologous proteins at different temperatures. In fact, for both eukaryotic and prokaryotic hosts, it has been reported that growth temperature affects the yield of properly folded recombinant proteins $[13,14]$. In E. coli a common strategy to express the target protein in a soluble state consists in evaluating different growth temperatures. Temperature lowering improves the solubility of the proteins by diminishing aggregation as a result of a decrease in the production rate, allowing the newly synthesized chain to fold properly $[15,16]$. Several studies explored the effect of the growth temperature on the expression and secretion of heterologous proteins also in yeasts, albeit, in most cases, the authors investigated limited arrays of temperatures, generally ranging between 15 and $30^{\circ} \mathrm{C}$ [17-19].

Herein, the impact of different temperatures on endogenous and recombinant protein production and secretion was assessed in $K$. marxianus within a wider range of temperatures, ranging between 5 and $40^{\circ} \mathrm{C}$. The reporter genes encoding the glucoamylase (GAA) from the yeast Arxula adeninivorans [20], the recombinant human serum albumin (HSA) [21], and the Kluyveromyces lactis $\mathrm{Cu}^{2+} / \mathrm{Zn}^{2+}$ superoxide dismutase (SOD1) [22] were used.

\section{Results and discussion}

To the best of our knowledge, the capability to grow both at mesophilic and psychrophilic temperatures has never been investigated for a unique eukaryotic host of recombinant proteins. Kluyveromyces marxianus can grow in a wide range of temperatures, it is still an underexploited biotechnological system, and few studies have so far explored its potential for heterologous protein production $[8,9]$. In the present work, $K$. marxianus has been challenged as a cell factory model to investigate the impact of temperature on the secretion efficiency of endogenous and recombinant proteins.

\section{Specific growth rate and biomass yield of Kluyveromyces marxianus $\mathrm{L} 3$}

Growth rate and biomass yield are physiological features of major importance for a "cell factory" organism in order to reach high volumetric productivities of recombinant proteins. It is generally assumed that growth at temperatures below the optimal value positively affects production and secretion of recombinant proteins. In this perspective, we investigated $K$. marxianus L3 specific growth rates $(\mu)$ and biomass yield $\left(\mathrm{g} \mathrm{L}^{-1}\right)$ at different temperatures $(5,15$, 30,40 , and $45^{\circ} \mathrm{C}$; Table 1), exploiting the advantage of this heat-tolerant yeast, which optimum temperature for growth falls generally around $42^{\circ} \mathrm{C}$.

As expected, the temperature markedly affected the specific growth rate $(\mu)$. The $\mu$ increased if the temperature raised, and it was highest at $45^{\circ} \mathrm{C}\left(0.464 \mathrm{~h}^{-1}\right)$. This behavior was in accordance with data reported in literature indicating that all the $K$. marxianus strains are able to grow at $42^{\circ} \mathrm{C}$, and only few strains can grow up to $48^{\circ} \mathrm{C}$ [23].

Biomass yields were slightly affected by temperature, with the highest values reached at 15 and $30^{\circ} \mathrm{C}(12.8$ and $12.9 \mathrm{~g} \mathrm{~L}^{-1}$, respectively). These high yields confirmed the excellent capability of $K$. marxianus to convert substrate into biomass [24]. The lower values at the highest temperatures (10.6 and $9.8 \mathrm{~g} \mathrm{~L}^{-1}$ at 40 and $45^{\circ} \mathrm{C}$, respectively) suggested that, even if the growth rate was high, cell reproduction at the highest temperature required a metabolic cost that affected the biomass yield.

\section{Secretion of endogenous $\beta$-fructofuranosidase}

In order to assess the secretory capability of the host strain $K$. marxianus L3, the activity of endogenous $\beta$ fructofuranosidase (EC 3.2.1.26) was analyzed in the supernatant of cultures grown between 5 and $45^{\circ} \mathrm{C}$. At all the tested temperatures, enzyme activity increased during both the growth and the stationary phases (Figure 1). The extracellular $\beta$-fructofuranosidase activity was temperature dependent, with the highest yield at $30^{\circ} \mathrm{C}$ (Figure 1). With the exception of $5^{\circ} \mathrm{C}$, the enzyme production was abundant also at lower and higher temperatures. This result was consistent with the data reported in literature [25-27], and confirmed that $K$. marxianus can be regarded as a good secretor, acting as a thermally flexible cell factory able to secrete active forms of an homologous enzyme in a wide range of temperatures.

\begin{tabular}{|c|c|c|c|c|c|c|}
\hline $\begin{array}{l}\mathrm{T} \\
\left({ }^{\circ} \mathrm{C}\right)\end{array}$ & $\begin{array}{l}\text { Wild-type } \\
\text { DW }\left(g^{-1}\right)\end{array}$ & $\begin{array}{l}\text { Wild-type } \\
Q_{x}\left(g^{-1} h^{-1}\right)\end{array}$ & $\begin{array}{l}\text { Wild-type } \\
\mu\left(h^{-1}\right)\end{array}$ & $\begin{array}{l}\text { rHSA } \\
\mu\left(h^{-1}\right)\end{array}$ & $\begin{array}{l}\text { GAA } \\
\mu\left(h^{-1}\right)\end{array}$ & $\begin{array}{l}\text { KISod1p } \\
\mu\left(h^{-1}\right)\end{array}$ \\
\hline 5 & $10.5^{\#}$ & 0.096 & 0.041 & $0.034^{a}$ & $0.031^{a}$ & $0.034^{\mathrm{a}}$ \\
\hline 15 & $12.8^{\ddagger}$ & 0.355 & 0.171 & $0.138^{a}$ & 0.160 & $0.144^{a}$ \\
\hline 30 & $12.9^{\ddagger}$ & 0.479 & 0.377 & $0.321^{a}$ & $0.341^{a}$ & 0.271 \\
\hline 40 & $10.6^{\#}$ & $0.443^{\ddagger}$ & 0.439 & $0.293^{\mathrm{a}}$ & 0.369 & $0.313^{\mathrm{a}}$ \\
\hline 45 & 9.8 & $0.426^{\ddagger}$ & 0.464 & - & - & - \\
\hline
\end{tabular}

The strains were cultured at different temperatures in YPD medium containing $20 \mathrm{~g} \mathrm{~L}^{-1}$ glucose. The specific growth rates $(\mu)$, the biomass yield (expressed as dry weight grams per litre of culture) and the biomass volumetric productivities $\left(Q_{X}\right)$ are reported as a function of growth temperature. The values are means of three independent experiments, with standard deviations always lower than $5 \%$. Superscripts within a column (symbols) and within a row (letters) indicate statistically similar means, $\mathrm{P}>0.05$. 


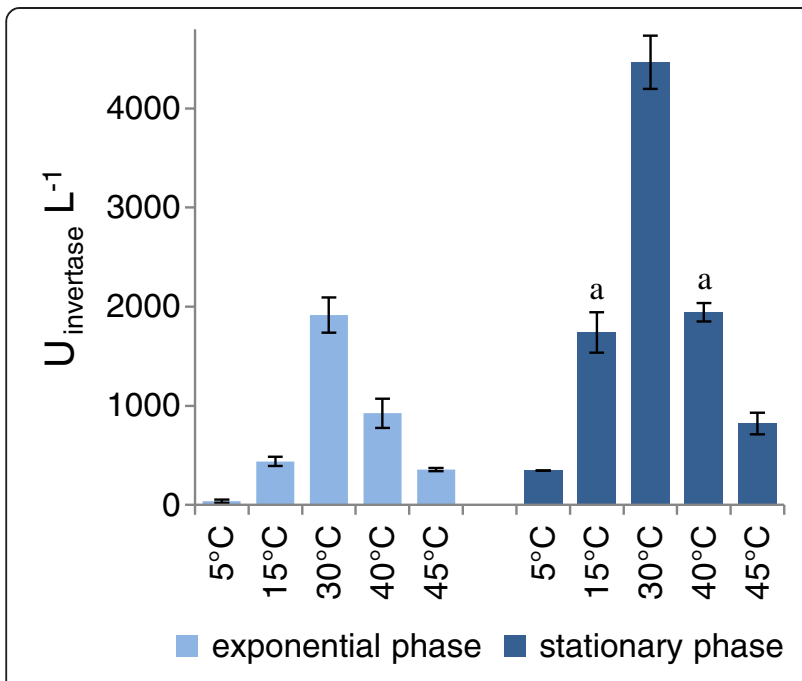

Figure 1 Effects of the growth temperature on secretion of the $\beta$-fructofuranosidase. $\beta$-fructofuranosidase has been measured as inulinase activity at $5-40^{\circ} \mathrm{C}$, both at the growth and stationary phases. The values are means of three independent experiments \pm standard deviations. Superscripts indicate statistically similar means $(P>0.05)$. Letters are used to compare samples collected at the same growth phase, grown at different temperatures. Symbols are used to compare samples grown at the same temperature, collected at diverse growth phases (exponential or stationary).

\section{Secretion of heterologous proteins}

In a previous study the comparison of expression and secretion of recombinant proteins at different temperatures has been carried out by using different hosts [28]. Herein, $K$. marxianus L3 was challenged for the secretion of three recombinant proteins in a wide range of temperatures. Specific growth rates $(\mu)$ were determined for each recombinant strain expressing the heterologous proteins HSA, GAA, or KlSod1p at 5, 15, 30, 40, and $45^{\circ} \mathrm{C}$ (Table 1 ). The recombinant strains were not able to grow at $45^{\circ} \mathrm{C}$, possibly because of a low segregational stability of recombinant plasmids at the highest growth temperature, as reported in both prokaryotic and eukaryotic hosts [29,30].

In the explored range of temperature, the $\mu$ increased by raising the temperature, with the exception of HSA

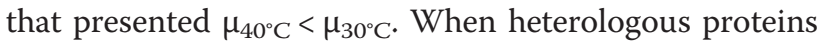
were expressed, generally $\mu$ were lower respect to the host (Table 1), reflecting a higher metabolic load [31,32].

\section{HSA production}

HSA was successfully produced and secreted in the range between 5 and $40^{\circ} \mathrm{C}$, and the growth phase affected specific HSA production (Figure 2A). The yields, expressed as relative abundances, showed a peak at $15^{\circ} \mathrm{C}$ both in exponential and stationary phases. A notably secretion efficiency was observed at all tested temperatures, when compared to the highest reference value $\left(100 \%\right.$ at $\left.15^{\circ} \mathrm{C}\right)$. Compared to secretion levels, intracellular HSA production in both the

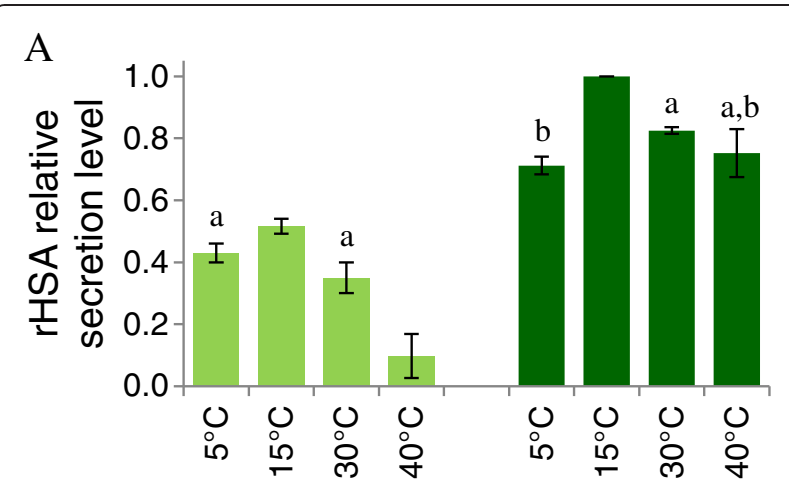

B
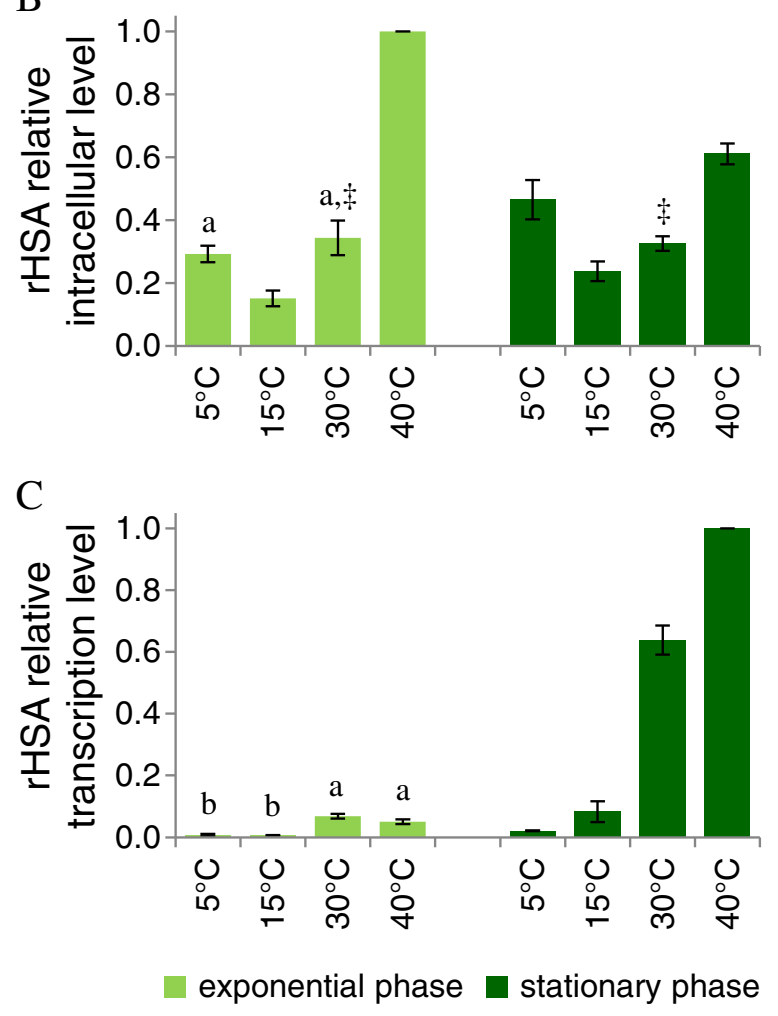

Figure 2 Effects of the growth temperature on HSA secretion. Culture samples, grown at $5-40^{\circ} \mathrm{C}$, have been analyzed both at the growth and stationary phases. A) Western blot analysis of secreted rHSA; B) Western blot analysis of intracellular rHSA; C) Q-PCR analysis of rHSA mRNA. Data are reported as a function of growth phase and temperature. The values, means of three independent experiments \pm standard deviations, have been normalized setting at 1 the highest value. Superscripts indicate statistically similar means $(P>0.05)$. Symbols are used to compare sample grown at the same temperature, collected at different growth phases (exponential or stationary). Letters are used to compare samples collected at the same growth phase, cultured at diverse temperatures.

exponential and stationary phases presented the opposite behavior, being the lowest at $15^{\circ} \mathrm{C}$ and the highest at $40^{\circ} \mathrm{C}$ (Figure 2B). Conceivably, the lower intracellular HSA at $15^{\circ} \mathrm{C}$ was associated to a more efficient secretion, and vice versa for the higher temperatures. A RT-PCR analysis was 
performed to determine transcription levels at the different temperatures (Figure $2 \mathrm{C}$ ). At $5^{\circ} \mathrm{C}$ and $15^{\circ} \mathrm{C}$ very low amounts of HSA mRNA were observed during both exponential and stationary phases. At the higher temperatures, the relative amount of the messenger was always greater in stationary phase, and increased by rising the temperature. Although high temperatures seem not to drive the $A D H 4$ promoter activity in $S$. cerevisiae or in K. lactis [33], we could not exclude this possibility in the $K$. marxianus background. This aspect will deserve further investigations.

\section{GAA production}

Heterologous GAA was successfully produced by $K$. marxianus at all the tested temperatures and the active enzyme accumulated in the medium over the time (Figure 3A). During the exponential phase production increased by rising the growth temperature up to $40^{\circ} \mathrm{C}$. In the stationary phase, the total amount of active GAA secreted in the medium was similar over the range of temperatures between 5 and $30^{\circ} \mathrm{C}$, whereas it was higher at $40^{\circ} \mathrm{C}$. Transcript analysis showed that the relative amount of GAA mRNA had a slight variation between $5^{\circ} \mathrm{C}$ and $30^{\circ} \mathrm{C}$ in both growth phases; a significant increase was instead observed at $40^{\circ} \mathrm{C}(\mathrm{p}<0.05)$ (Figure $\left.3 \mathrm{~B}\right)$.

\section{KISod1p production}

The secretion efficiency of active Sod1p was compared at different temperatures by quantitative analysis of zymogram bands (Figure 4A). During the exponential phase, the capability to secrete active Sod1p increased by lowering the temperature. In stationary phase the production of active enzyme was similar between $5^{\circ} \mathrm{C}$ and $30^{\circ} \mathrm{C}$ and was significantly reduced at $40^{\circ} \mathrm{C}$.

Transcriptional analysis showed that SOD1 expression was almost not responsive to temperature up to $30^{\circ} \mathrm{C}$; the level of transcript increased significantly at $40^{\circ} \mathrm{C}$ (Figure $4 \mathrm{~B})$. Actually, the genes KmSOD1 of $K$. marxianus and KlSOD 1 of $K$. lactis present a $83 \%$ identity, it is then conceivable that the employed probe hybridized to both transcripts. Furthermore, endogenous Sod1p should be upregulated as a key part of a heat shock response. In $S$. cerevisiae oxidative stress and antioxidant enzymes play a pivotal role in heat-induced cell death and it has been observed that overexpression of catalase and superoxide dismutase genes caused increased thermotolerance [34].

Taken together, our results support $K$. marxianus L3 as a thermally flexible cell factory. This strain can be adopted in a process optimized for the 'most productive temperature' whenever no particular constraints were placed by the produced protein. Conversely, the strain L3 can be employed at the 'most suitable temperature' in case of specific protein requirements (e.g. stability at low temperature).
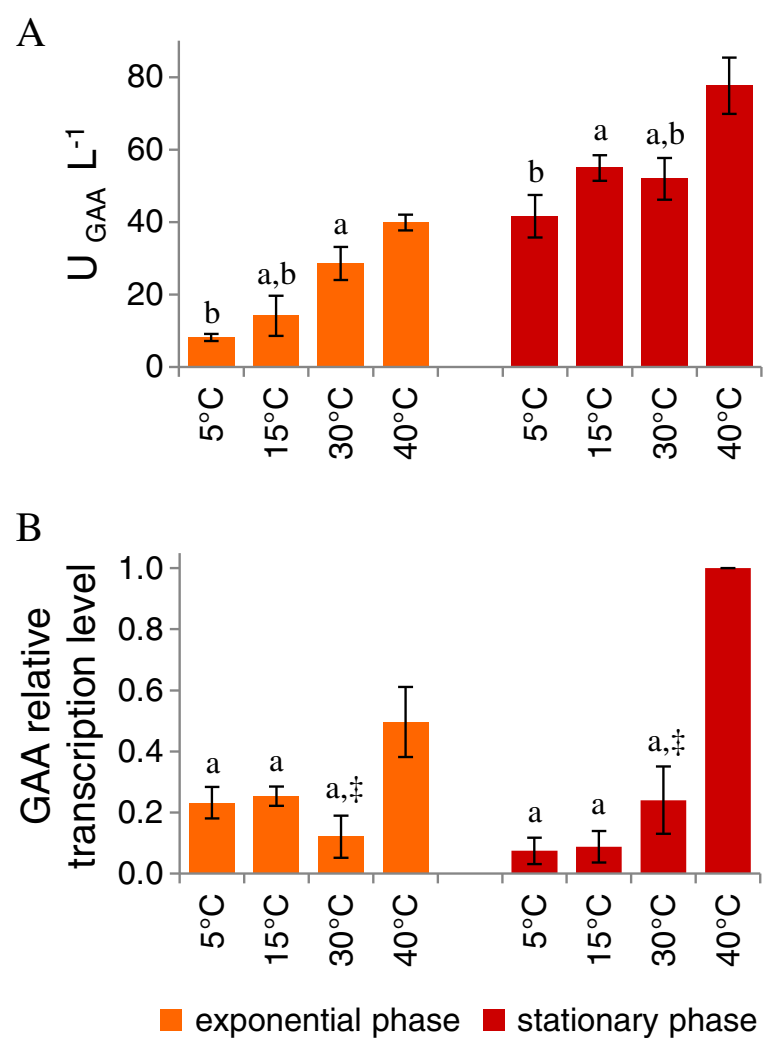

Figure 3 Effects of the growth temperature on GAA secretion. Culture samples, grown at $5-40^{\circ} \mathrm{C}$, have been analyzed both at the growth and stationary phases. A) extracellular GAA activity; B) northern blot analysis of GAA mRNA. Data are means of three independent experiments \pm standard deviations. The values, means of three independent experiments \pm standard deviations, have been normalized setting at 1 the highest value. Superscripts indicate statistically similar means $(P>0.05)$. Symbols are used to compare samples grown at the same temperature, collected at different phases (exponential or stationary). Letters are used to compare samples collected at the same growth phase, cultured at different temperatures.

\section{Conclusions}

In this study, the yeast $K$. marxianus has proved to be a handy model system to investigate the impact of temperature on cell factory efficiency. It resulted in a thermally flexible host able to produce and secrete three different recombinant proteins between 5 and $40^{\circ} \mathrm{C}$. Notably, for the first time, the impact of a wide range of temperatures on the production of diverse heterologous proteins has been explored by using a single biotechnological platform. A peculiar behavior of each recombinant protein with respect to the temperature was observed, strengthening the advantage of using $K$. marxianus as unique host. Because of its ability to grow between $5^{\circ} \mathrm{C}$ and $40^{\circ} \mathrm{C}$, and efficiently secrete heterologous proteins, it can be exploited as a first-strike model system to study the temperature tuning and optimization of the production. Moreover $K$. marxianus 


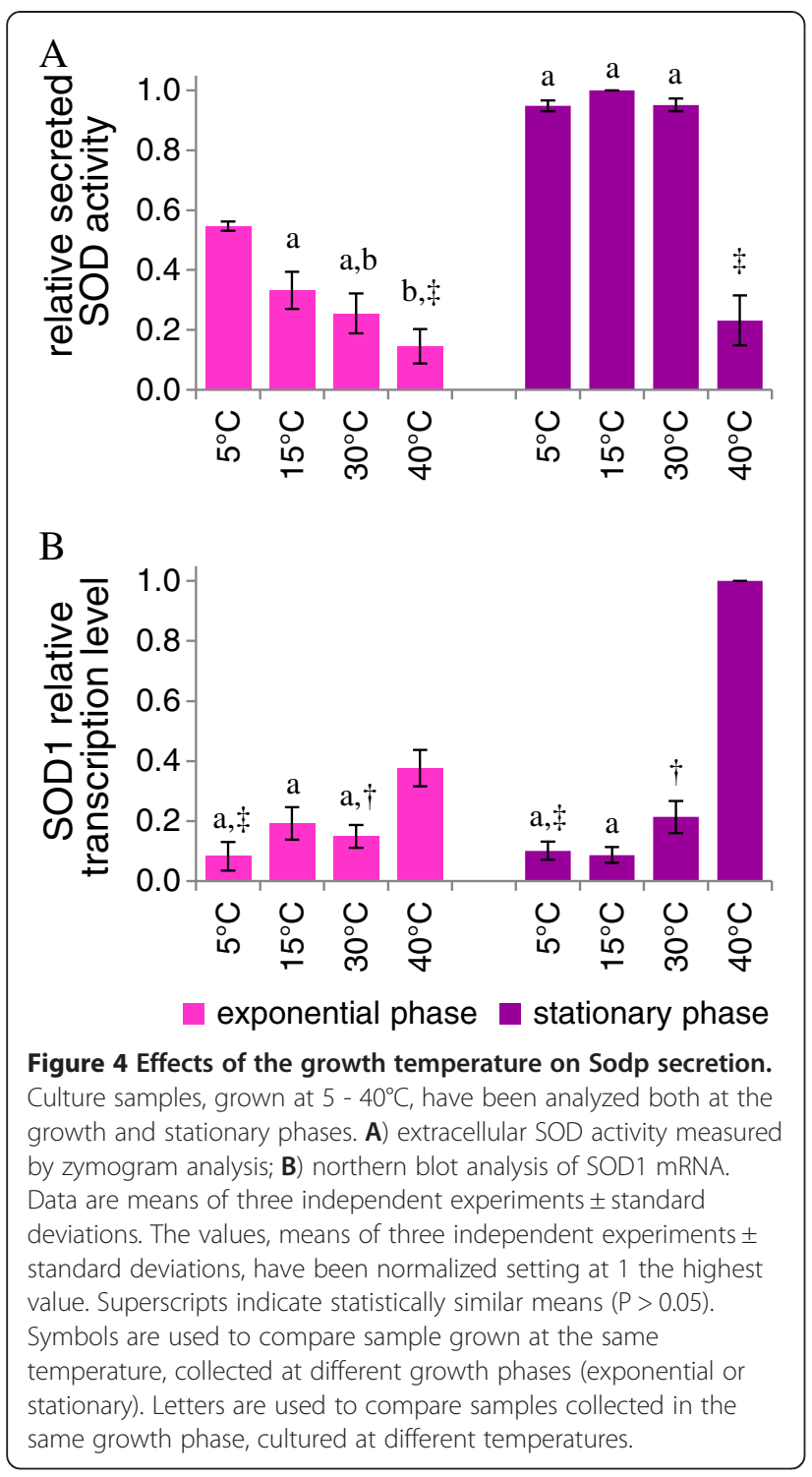

meets the criteria of process safety and the demand for fast growth and high yield biomass.

\section{Methods}

\section{Strains and media}

Kluyveromyces marxianus L3 [35] was used as expression host. Yeast cells were grown in YPD medium $\left(10 \mathrm{~g} \mathrm{l}^{-1}\right.$ yeast extract, $10 \mathrm{~g} \mathrm{l}^{-1}$ peptone, and $20 \mathrm{~g} \mathrm{l}^{-1}$ glucose). Supplement of antibiotic G418 $\left(0.2 \mathrm{~g} \mathrm{l}^{-1}\right)$ was added for the maintenance of recombinant plasmids. Standard batch cultures were carried out in $500 \mathrm{ml}$ baffled Erlenmeyer flasks with $50 \mathrm{ml}$ YPD medium. Flasks were inoculated $(10 \% \mathrm{v} / \mathrm{v})$ with exponential phase cultures, grown at the same temperature, to an $\mathrm{OD}_{600}$ of 1.0 , then were incubated at 5,15 , 30,40 , and $45^{\circ} \mathrm{C}$ for $7,4,3,2$ and 2 days, respectively. For each cultures, samples corresponding to the exponential growth phase and to the stationary phase were analyzed.
For strains harboring the plasmids pYG-KIKlSOD1 [22] and pGAM-GAM [20], heterologous protein expression was induced after $24 \mathrm{~h}$ of growth by the addition of ethanol to a final concentration of $2 \% \mathrm{v} / \mathrm{v}$. All the experiments were performed in triplicate.

Escherichia coli DH5a ( 80 lacZ $\triangle M 15$, recA1, end A1, gyr A96, thi-1, hsd R17, rel A1) was used for general cloning purposes.

\section{Plasmids and DNA manipulation}

The pGM-GAM, pYG132, and pYG-K1KISOD1 plasmids were utilized for the expression of the reporter proteins. pGM-GAA contains the glucoamylase (GAA) gene from the yeast Arxula adeninivorans under the control of the $S$. cerevisiae GAPDH promoter and of the S. cerevisiae PHO5 terminator [20]. pYG132 harbors an expression cassette for the secretion of the recombinant human serum albumin (HSA), driven by the native signal sequence, under the control of the ethanol inducible K. lactis ADH4 promoter and of the $K$. lactis $P G K$ terminator [21]. pYGK1KlSOD1 carries the $K$. lactis KlSOD1 gene encoding the the $\mathrm{Cu}^{2+} / \mathrm{Zn}^{2+}$ superoxide dismutase fused with the $\mathrm{K} 1 \mathrm{se}-$ cretion signal, under the control of the $K$. lactis ADH4 promoter and $P G K$ terminator [22]. K. marxianus L3 was transformed by electroporation with a Biorad Gene-Pulser apparatus, as reported in Raimondi et al. [22].

\section{Calculation of the specific growth rate, biomass yield and volumetric productivity}

For biomass determination, an appropriate volume of the culture was centrifuged. The pellet was washed in $\mathrm{d}$. d. water and was desiccated under an infrared heat lamp. The dry weight was determined gravimetrically and the biomass yield was expressed as grams of dry weight per litre of culture broth. The specific growth rate $(\mu)$ was calculated using dry weight values in the exponential phase of the growth curve. Glucose consumption was analyzed by an HPLC equipped with refractive index detector (HPLC System, 1200 Series, Agilent Technologies, Santa Clara, CA). The analysis was performed with an Aminex HPX-87H ion exclusion column and $0.005 \mathrm{M}$ $\mathrm{H}_{2} \mathrm{SO}_{4}\left(0.6 \mathrm{ml} \mathrm{min}^{-1}\right)$ as the mobile phase. The volumetric productivities of biomass $\mathrm{Q}_{\mathrm{x}}$ were calculated by dividing the biomass yield with the corresponding culture time.

\section{$\beta$-fructofuronidase activity}

$\beta$-fructofuronidase was determined as inulinase activity according to Burkert et al. [36]. Culture was centrifuged for 5 minutes at $18000 \mathrm{~g}$ and $1 \mathrm{ml}$ of supernatant, properly diluted in acetate buffer $0.1 \mathrm{M}$ at pH 5, was mixed with $9 \mathrm{ml}$ of $20 \mathrm{~g} \mathrm{l}^{-1}$ sucrose dissolved in acetate buffer. The sample was incubated at $60^{\circ} \mathrm{C}$ and the rate of glucose and fructose production was determined by the 3,5-dinitrosalicylic acid method [37]. One unit of invertase is defined as the amount 
of enzyme catalyzing the liberation of $1 \mu \mathrm{mol}$ of reducing sugars per minute under the conditions above mentioned.

\section{Western-blot analysis of recombinant HSA}

For HSA Western-blot analysis, proteins from the supernatant (10 $\mu$ l of 1:10 dilution) were separated with SDS-PAGE using the buffer system of Laemmli [38] and $12 \%$ acrylamide gels. After electroblotting onto a polyvinylidene difluoride membrane (Biorad), target proteins were detected with specific polyclonal antibodies of rabbit. Anti-HSA primary antibodies (Sigma) were used in 1:10,000 dilution. Monoclonal anti-rabbit IgG conjugated with peroxidase (Promega) were used as secondary antibodies. Immunologically active proteins were visualized with enhanced chemiluminescence detection system (GE Healthcare), according to the manufacturer's instructions. The densitometric analysis was performed with an image analyzer (Phoretix 1D; Non Linear Dynamics Ltd.).

\section{RT-PCR analysis}

Total RNA of $K$. marxianus cells was extracted by the hot phenol method [39]. RNA was quantified by absorbance $\left(A_{260}\right)$ and subjected to TURBO DNase treatment according to the manufacturer's instructions (Ambion). Reverse transcription was performed using a Promega Reverse Transcription System with $1 \mu \mathrm{g}$ total RNA to yield $20 \mu \mathrm{l}$ cDNA. After cDNA generation, samples were purified, quantified with Nanodrop ${ }^{\mathrm{TM}} 3300$ (Thermo Scientific), diluted with DEPC water (Ambion) to a final concentration of $10 \mathrm{ng}^{-1} \mathrm{l}^{-1}$, and $2 \mu \mathrm{l}$ were used for SYBR Green SensiMix (Bioline). Oligonucleotides (purchased from SIGMA) were designed with Primer3 (http://frodo. wi.mit.edu/primer3/ website), considering an amplicon size of $95-220 \mathrm{bp}$ and a Tm of approximately $55^{\circ} \mathrm{C}$. For the HSA the primers used were $5^{\prime}$ - GTTGCAACT CTTCGTGAAAC- $3^{\prime}$ and $5^{\prime}$ - AAGTAAGGATGTCTTC TGGC-3'; for the KmACT1 they were $5^{\prime}$ - CTCCTT GCCTCATGCTATC- $3^{\prime}$ and $5^{\prime}$-GAAGGAGTAACCACG TTCAG-3'.

\section{Glucoamilase activity}

GAA activity was determined at $37^{\circ} \mathrm{C}$ as starch-hydrolyzing activity of the cell-free culture broths, according to Morlino et al. [20] One unit of GAA activity was defined as the quantity of enzyme needed to decrease the absorbance at $580 \mathrm{~nm}$ by one absorbance unit per minute. GAA activity was expressed as volumetric activity $\left(\mathrm{U} \mathrm{l}^{-1}\right)$.

\section{Superoxide dismutase activity}

SOD activity was determined by on native gel by the nitroblue tetrazolium method [40]. During illumination with light, the gel became uniformly blue-purple except at positions containing active SOD protein. The densitometric analysis was carried out with the image analyzer Phoretix 1D (Non Linear Dynamics Ltd).

\section{Northern blot analysis}

Total RNA was prepared by extraction with hot acidic phenol [41]. Northern blot analysis was performed as previously described according to Sambrook et al. [42]. The $A$. adeninivorans GAA probe corresponded to the $2.1-\mathrm{kb}$ HindIII region of the pGM-GAM plasmid. The $0.7 \mathrm{~kb}$ fragment of the KlKlSOD1 gene, amplified using the set of primers K1-KISOD1_f (5'-GC AAG CTT ATG AAT ATA TTT TAC ATA TTT TTG TTT TTG CTG TCA TTC GTT CAA GGT ACC CGG GGA GTT AAT GCA GTT GCA G-3') and KISOD1_r (5'-GC AAG CTT TTA AGC GTT AGA GAT ACC-3'), was used to detect KlSOD1 mRNA. The probes were labeled with $\left[\alpha-{ }^{32} \mathrm{P}\right] \mathrm{dATP}$ by use of the Ready Prime DNA labeling system (GE Healthcare), according to the manufacturer's instructions.

\section{Statistical analysis}

All values are means of three separate experiments. Differences in means were analyzed using Student's $t$ test with independent measures. Differences were considered statistically significant if $\mathrm{P}<0.05$.

\section{Competing interests}

The authors declare that they have no competing interests.

\section{Authors' contributions}

SR, DU and MR conceived the study, participated in its design and wrote the manuscript. SR, EZ, and AA performed the experimental work and drafted the manuscript. CP has been involved in drafting the manuscript and revising it critically. All authors read and approved the final manuscript.

Received: 21 December 2012 Accepted: 26 March 2013

Published: 15 April 2013

\section{References}

1. Iborra F: High efficiency transformation of Kluyveromyces marxianus by a replicative plasmid. Curr Genet 1993, 24:181-183.

2. Fonseca GG, Heinzle E, Wittmann C, Gombert AK: The yeast Kluyveromyces marxianus and its biotechnological potential. Appl Microbiol Biotechnol 2008, 79:339-354.

3. Diniz RH, Silveira WB, Fietto LG, Passos FM: The high fermentative metabolism of Kluyveromyces marxianus UFV-3 relies on the increased expression of key lactose metabolic enzymes. Antonie Van Leeuwenhoek 2012, 101:541-550.

4. Dos Santos VC, Bragança CR, Passos FJ, Passos FM: Kinetics of growth and ethanol formation from a mix of glucose/xylose substrate by Kluyveromyces marxianus UFV-3. Antonie Van Leeuwenhoek 2013, 103:153-161.

5. López-Alvarez A, Díaz-Pérez AL, Sosa-Aguirre C, Macías-Rodríquez L, Campos-García J: Ethanol yield and volatile compound content in fermentation of agave must by Kluyveromyces marxianus UMPe-1 comparing with Saccharomyces cerevisiae baker's yeast used in tequila production. J Biosci Bioeng 2012, 113(5):614-618.

6. Lee KS, Kim JS, Heo P, Yang TJ, Sung YJ, Cheon Y, Koo HM, Yu BJ, Seo JH, Jin YS, Park JC, Kweon DH: Characterization of Saccharomyces cerevisiae promoters for heterologous gene expression in Kluyveromyces marxianus. Appl Microbiol Biotechnol 2012. Epub ahead of print.

7. Jeong H, Lee DH, Kim SH, Kim HJ, Lee K, Song JY, Kim BK, Sung BH, Park JC, Sohn JH, Koo HM, Kim JF: Genome sequence of the thermotolerant yeast Kluyveromyces marxianus var. marxianus KCTC 17555. Eukaryot Cell 2012, 11(12):1584-1585 
8. Rocha SN, Abrahão-Neto J, Cerdán ME, Gombert AK, González-Siso MI: Heterologous expression of a thermophilic esterase in Kluyveromyces yeasts. Appl Microbiol Biotechnol 2011, 89:375-385.

9. Rocha SN, Abrahão-Neto J, Cerdán ME, González-Siso MI, Gombert AK: Heterologous expression of glucose oxidase in the yeast Kluyveromyces marxianus. Microb Cell Fact 2010, 9:4

10. Raimondi S, Uccelletti D, Amaretti A, Leonardi A, Palleschi C, Rossi M: Secretion of Kluyveromyces lactis Cu/Zn SOD: strategies for enhanced production. Appl Microbiol Biotechnol 2010, 86:871-878.

11. Foukis A, Stergiou PY, Theodorou LG, Papagianni M, Papamichael EM: Purification, kinetic characterization and properties of a novel thermotolerant extracellular protease from Kluyveromyces marxianus IFO 0288 with potential biotechnological interest. Bioresour Technol 2012, 123:214-220.

12. Rossi M, Buzzini P, Cordisco L, Amaretti A, Sala M, Raimondi S, Ponzoni C, Pagnoni UM, Matteuzzi D: Growth, lipid accumulation, and fatty acid composition in obligate psychrophilic, facultative psychrophilic, and mesophilic yeasts. FEMS Microbiol Ecol 2009, 69:363-372

13. García-Fruitós E, Vazquez E, Gonzalez-Montalbán N, Ferrer-Miralles N, Villaverde A: Analytical approaches for assessing aggregation of protein biopharmaceuticals. Curr Pharm Biotechnol 2011, 12:1530-1536.

14. Maldonado LMTP, Hernández VEB, Rivero EM, de la Rosa AP B, Flores JLF, Acevedo LGO, De León Rodríguez A: Optimization of culture conditions for a synthetic gene expression in Escherichia coli using response surface methodology: the case of human interferon beta. Biomol Eng 2007, 24:217-222

15. Noguère $C$, Larsson AM, Guyot JC, Bignon C: Fractional factorial approach combining 4 Escherichia coli strains, 3 culture media, 3 expression temperatures and $5 \mathrm{~N}$-terminal fusion tags for screening the soluble expression of recombinant proteins. Protein Expr Purif 2012, 84:204-213.

16. Baneyx F, Mujacic M: Recombinant protein folding and misfolding in Escherichia coli. Nat Biotechnol 2004, 22:1399-1408.

17. Dragosits M, Stadlmann J, Albiol J, Baumann K, Maurer M, Gasser B, Sauer M, Altmann F, Ferrer P, Mattanovich D: The effect of temperature on the proteome of recombinant Pichia pastoris. J Proteome Res 2009, 8:1380-1392.

18. Li Z, Xiong F, Lin Q, D'Anjou M, Daugulis AJ, Yang DS, Hew CL: Lowtemperature increases the yield of biologically active herring antifreeze protein in Pichia pastoris. Protein Expr Purif 2001, 21:438-445.

19. Gasser B, Maurer M, Rautio J, Sauer M, Bhattacharyya A, Saloheimo M, Penttilä M, Mattanovich D: Monitoring of transcriptional regulation in Pichia pastoris under protein production conditions. BMC Genomics 2007, 8:179.

20. Morlino GB, Tizzani L, Bianchi MM, Frontali L: Inducible amplification of gene copy number and heterologous proten production in the yeast Kluyveromyces lactis. Appl Environ Microbiol 1999, 65:4808-4813.

21. Saliola M, Mazzoni C, Solimando N, Crisà A, Falcone C, Jung G: FleerR: Use of the KIADH4 promoter for ethanol-dependent production of recombinant Human Serum Albumin in Kluyveromyces lactis. Appl Environ Microbiol 1999, 65:53-60.

22. Raimondi S, Uccelletti D, Matteuzzi D, Pagnoni UM, Rossi M, Palleschi C: Characterization of the superoxide dismutase SOD1 gene of Kluyveromyces marxianus L3 and improved production of SOD activity. Appl Microbiol Biotechnol 2008, 77:1269-1277.

23. Lane MM, Burke N, Karreman R, Wolfe KH, O'Byrne CP, Morrissey JP: Physiological and metabolic diversity in the yeast Kluyveromyces marxianus. Antonie Van Leeuwenhoek 2011, 100:507-519.

24. Fonseca GG, Gombert AK, Heinzle E, Wittmann C: Physiology of the yeast Kluyveromyces marxianus during batch and chemostat cultures with glucose as the sole carbon source. FEMS Yeast Res 2007, 7:422-435.

25. Masoud $W$, Jespersen $L$ : Pectin degrading enzymes in yeasts involved in fermentation of Coffea arabica in East Africa. Int J Food Microbiol 2006, 110:291-296.

26. Arrizon J, Morel S, Gschaedler A, Monsan P: Purification and substrate specificities of a fructanase from Kluyveromyces marxianus isolated from the fermentation process of Mezcal. Bioresour Technol 2011, 102:3298-3303.

27. Rouwenhorst RJ, Ritmeester WS, Scheffers WA, Van Dijken JP: Localization of inulinase and invertase in Kluyveromyces species. Appl Environ Microbiol 1990, 56:3329-3336.

28. Dragosits M, Frascotti G, Bernard-Granger L, Vázquez F, Giuliani M, Baumann K, Rodríguez-Carmona E, Tokkanen J, Parrilli E, Wiebe MG, Kunert R, Maurer M, Gasser B, Sauer M, Branduardi P, Pakula T, Saloheimo M, Penttilä M, Ferrer P, Luisa Tutino M, Villaverde A, Porro D, Mattanovich D: Influence of growth temperature on the production of antibody Fab fragments in different microbes: a host comparative analysis. Biotechnol Prog 2011, 27:38-46.

29. Zhang Y, Li T, Liu J: Low temperature and glucose enhanced T7 RNA polymerase-based plasmid stability for increasing expression of glucagons-like peptide-2 in Escherichia coli. Protein Expr Purif 2003, 29:132-139.

30. Zhang Z, Moo-Young M, Chisti Y: Plasmid stability in recombinant Saccharomyces cerevisiae. Biotechnol Adv 1996, 14:401-435.

31. Glick BR: Metabolic load and heterologous gene expression. Biotechnol Adv 1995, 13:247-261.

32. Neubauer $P$, Lin HY, Mathiszik B: Metabolic load of recombinant protein production: inhibition of cellular capacities for glucose uptake and respiration after induction of a heterologous gene in Escherichia coli. Biotechnol Bioeng 2003, 83:53-64.

33. Mazzoni C, Santori F, Saliola M, Falcone C: Molecular analysis of UAS(E), a cis element containing stress response elements responsible for ethanol induction of the KIADH4 gene of Kluyveromyces lactis. Res Microbiol 2000, 151:19-28.

34. Davidson JF, Whyte B, Bissinger PH, Schiestl RH: Oxidative stress is involved in heat-induced cell death in Saccharomyces cerevisiae. PNAS 1996, 93:5116-5121.

35. Dellomonaco C, Amaretti A, Zanoni S, Pompei A, Matteuzzi D, Rossi M: Fermentative production of superoxide dismutase with Kluyveromyces marxianus. J Ind Microbiol Biotechnol 2007, 34:27-34.

36. Burkert JFM, Kalil SJ, Maugeri Filho F, Rodrigues MI: Parameters optimization for enzymatic assays using experimental design. Braz J ChemEng 2006, 23:163-170

37. Miller GL: Use of dinitrosalisylic acid reagent for determination of reducing sugar. Anal Chem 1959, 31:426-428.

38. Laemmli UK: Cleavage of Structural Proteins during the Assembly of the Head of Bacteriophage T4. Nature 1970, 227:680-685.

39. Schmitt ME, Brown TA, Trumpower BL: A rapid and simple method for preparation of RNA from Saccharomyces cerevisiae. Nucleic Acids Res 1990, 18:3091-3092

40. McCord JM, Keele BB, Fridovich I: An enzyme-based theory of obligate anaerobiosis: the physiological function of superoxide dismutase. Proc Natl Acad Sci 1971, 68:1024-1027.

41. Ausubel FM, Brent R, Kingston RE, Moore DD, Seidman JG, Smith JA, Struhl K: Current protocols in molecular biology. New York: Greene Publishing Associates and Wiley-Interscience; 1994.

42. Sambrook J, Fritsch EF, Maniatis T: Molecular cloning: a laboratory manual. 2nd edition. New York, NY: Cold Spring Harbor Laboratory Press; 2001.

doi:10.1186/1475-2859-12-34

Cite this article as: Raimondi et al:: Thermal adaptability of

Kluyveromyces marxianus in recombinant protein production. Microbial Cell Factories 2013 12:34.

\section{Submit your next manuscript to BioMed Central and take full advantage of:}

- Convenient online submission

- Thorough peer review

- No space constraints or color figure charges

- Immediate publication on acceptance

- Inclusion in PubMed, CAS, Scopus and Google Scholar

- Research which is freely available for redistribution 